How to cite this article:

Kaya, Y. C., \& Kiprizli, G. (2019). Does democratic peace theory genuinely envision global peace? A critical approach. Journal of International Studies, 15, 73-86.https:// doi.org/10.32890/jis2019.15.5

\title{
Does Democratic Peace Theory Genuinely Envision Global Peace? A Critical Approach
}

\author{
Yasin Caglar Kaya \& ${ }^{1}$ Goktug Kiprizli \\ Karadeniz Technical University
}

Karadeniz Teknik Üniversitesi, İktisadi ve İdari Bilimler Fakültesi,

Uluslararası İlişkiler Bölümü, 61080, Ortahisar, Trabzon, Türkiye

'Corresponding author: goktugkiprizli@ktu.edu.tr

DOl: https://doi.org/10.32890/jis2019.15.5

Received: 20/2/2019

Revised: 1/10/2019

Accepted: 7/10/2019

Published: 31/12/2019

\begin{abstract}
Democratic Peace Theory has been one of the most hotly debated topics ever since the 1980s. From Kant to the present day, the meaning of Democratic Peace Theory has changed, while the theory nowadays claims in principle that democratic states wage war against each other less often owing to their institutions' and citizens' abilities to urge their governments to establish a peaceful foreign policy. At this point, the critical theory offers an alternative explanation for the behaviors of democratic countries. This study was designed as a theoretical discussion utilising the analysis of primary and secondary sources in the field, both in printed and electronic materials. Employing the viewpoint of the critical theory, this paper argues that Democratic Peace is the disguise of hegemonic relations and the product of the historical block. This study revealed that democracies are not pacifist actors in the international realm. As articulated by the critical approach, the study also puts forth that the concept of Democratic peace facilitates the expansionist ambitions of hegemonic powers in the international system by utilizing various humanitarian interventions and serves as a means to maintain imperialist peace. Empirical evidence from the military intervention in Libya further reinforces this argument. Thus, this study asserts the idea to be cautious against the propositions of the Democratic Peace Theory because any activities done in the name of spreading democracy may involve a hidden agenda and disrupt the internal stability of non-democratic countries.
\end{abstract}

Keywords: Democratic Peace Theory, critical theory of international relations, hegemony, historical block, imperialist peace, 2011 Libya military invasion. 


\section{Introduction}

Theoretical discourse on democracy and peace is not new in the study of international relations. One of the most frequently debated theories in explaining this issue is the Democratic Peace Theory (DPT). However, its emergence has been met with both supports and criticisms. For Kant (1957), peace is possible only if states adopt republican principles in their internal affairs, respect human rights and voluntarily join an international organization whose aim is to promote peace.

According to Small and Singer (1976) and Doyle (1983), the Democratic Peace Theory does not suggest that democratic states are not war prone as autocracies, but that they are as hostile as autocracies, if not more. Still, the theory makes two significant assertions. First, democracies never or occasionally wage war against other democracies. Second, when democracies get into disagreements with democratic counterparts, they usually do not resort to threats of using force because it is "illegal". The theory explains the behaviors displayed by democratic states in two different ways. On the one hand, the institutional structure of democratic states balances their domestic and foreign policies and generates non-violent interactions, while on the other hand, the norms and culture shared among democratic counterparts lead to peaceful conflict resolutions. The peaceful relations among democratic states are usually attributed to these concepts.

This theory has become a very hot issue in international relations and has been one of the most, if not the most, discussed topics since the 1980s. Numerous empirical studies have been conducted to show its accuracy. In the late 1990s, the theory began to be criticized by other academicians, who made their analysis by employing a realist perspective. However, it can be argued that these critics fell short in explaining the different behaviors displayed by democratic states towards democracies and autocracies. Both the Democratic Peace Theory and its critics, adopting a realist understanding, mostly overlooked the economic relations and ignored the unipolar "hegemonic structure". However, in order to fully understand the reasons behind these behavioral differences among states, the Democratic Peace Theory should be examined from the viewpoint of the critical theory.

The critical theory suggests that the peaceful status among the democracies is not bound by whether countries are being ruled by democracy, but it is closely related to the common economic values they share and the dominant systemic structure. The critical theory evaluates the Democratic Peace Theory not only within the scope of center-periphery. Barkawi and Laffey (2001) assert that democratic peace is actually an "imperialist peace" that envisages a "cartel" - like cooperation among imperialist states. As stated above, empirical studies found that democratic states are not more peaceful than autocratic states. So, the peaceful effects of democracy only occur in relations with other democracies. This may be attributable to the general principles of the Democratic Peace Theory but it also contradicts the institutional definitions of the theory. If the accountability and the checks and balances mechanisms in democracies prompt democracies to settle conflicts in a peaceful manner, these mechanisms should function in all states regardless of their regimes (Barkawi and Laffey, 2001). This 
supports the assumption of the Marxist school of thought which suggests that developed democratic countries are war prone in general and thus democratic peace is serving as a means to maintain their prevailing position in the international system. The critical theory emphasizes that the liberal constitution created by western democracies is designed to prosper the liberal system and preserve their hegemony. Democratic peace, delimiting war between western liberal countries, however, promotes war against third world countries.

Although numerous studies about the liberal peace theory are available in the literature, there is an important gap about the discussion on the analysis of DTP within the framework of the Critical International Relations Theory (CIRT). Moreover, the studies employing the critical theory do not deal with the analysis of DPT thoroughly. In this respect, this study intended to fill the mentioned gap by emphasizing the arguments developed in the critical theory.

The aim of this study was to evaluate the Democratic Peace Theory by adopting the perspective of the Critical Theory. In this regard, the analytical framework method was employed in the study. The study first provides a literature review on the discussion of the Democratic Peace Theory together with its historical evolution, after which the Democratic Peace Theory is explained on the basis of its principles and practices by asking what the Democratic Peace Theory actually stands for. The final section employs the critical theory of international relations in analyzing the DPT, with the intent to elucidate the weaknesses of the Democratic Peace approach.

\section{The DPT and Its Critiques}

Kant (1957), in his work named "Perpetual Peace", asserts that the expected outcome of the interaction between republican states is to establish a peaceful environment. He strongly believed that achieving perpetual peace solely depended on the constitution of the republics. According to him, leaders would not declare war against other states without gaining the consent of their subjects since it would jeopardize their position if they overlooked the reactions of their citizens in future elections. It is expected that citizens would not give their consent for initiating war since such an act would be expensive, destructive and depressing. However, states that are not ruled by democracy feel free to act recklessly because the opinion of the society does not concern the ruler in any respect. Nevertheless, the arguments developed by Kant are only applicable if the counterparts in hand are ruled by democracy and so war would be unnecessary. Yet, war may serve as a means to diffuse democracy towards autocratic regimes on account that they oppress their citizens. Therefore, democracy is seen as a potential source of threat by autocratic regimes because it may threaten the existence of their regimes but it may be welcomed by other democratic states since they share and treasure the same values (Pugh, 2005).

Doyle (1986), agreeing with the arguments of Kant, asserts that peace and freedom can only be achieved by accepting liberal principles. Liberalism covers civil rights, freedom in 
elections, institutions, equality before law, and economy which is determined by supply and demand (Doyle, 1996). Whereas Doyle renewed the theory conceptualized within the Kantian perspective and made it more systematical, Oneal and Russet (1997) improved and defined the theory at the international level. They tried to incorporate realist ideas. They remodeled the theory by making two different segregations, namely cultural-normative and structuralinstitutional (Pazienza, 2014). Russet and Oneal (2001) coined the term "Triangulating Peace" which put forward that democracy, capitalism, international organizations and peace are interrelated and these notions contribute to democratic peace.

Schumpeter (1950) also considered trade, capitalism and liberalism as the foundation of international peace. His argument was plain and simple; "no one gains anything useful from war except aristocrats and autocrats" (Schumpeter, 1950). Therefore, one would not expect democracies to pursue war or any kind of intervention in other states. With the wide acceptance of free trade and liberal economy, sources have become accessible for every state around the world without any boundaries (Schumpeter, 1955). His understanding of democracy complies with the liberal economic structure. However, his views on democratic peace can be easily discarded because the United States, which is the flag-bearer of global liberalism and capitalist economy, declared a considerable number of wars and made more international interventions than any other state after 1945.

Moreover, realists and neo-realists argue that peace is only an illusion and trust, and understanding between states can never be established in the real sense. Layne (1994) tested the Democratic Peace Theory on the example of the Anglo-American Crisis I (The Trent Affair), the Anglo-American Crisis II (Venezuela), the Anglo-French struggle for control of the Nile (Fashoda), and the Franco-German crisis (The Ruhr) in order to determine the causes of peace after World War II. He found that peace was achieved not because of democracy but because of mutual deterrence and hegemony. He claimed that even if both parties were democracies, the states involved in conflict would not act in the framework of "norms" as would be assumed under the Democratic Peace Theory, but their acts and behaviors would be shaped by what one would expect from the perspective of realist understanding, namely by pride and power.

Rosato (2003) claims that the Democratic Peace Theory is a sugar-coated version of imperialist peace which originated in the United States. He supports this claim by observing the international system after World War II. His findings point out that the institutionalized version of the Democratic Peace Theory is a product of World War II supervised by the United States, the post- 1945 hegemonic power and its Western allies. Therefore, this arrangement has been reshaping the international and regional organizations and the concept of peace. The peace that the Democratic Peace Theory speaks of is nothing more than a concept propounded by the United States in order to sustain its hegemony and imperial ambitions. It would not be possible to sustain the peace designed by the US if the US lost its hegemonic position. 
The critique of the Democratic Peace Theory made by economic structuralists is founded on the theory's arguments on the economic and hierarchical structure. Barkawi and Laffey (1999) agree that democratic states do not tend to fight each other, however, the reason is not the regime of the states, but the spread of globalization and its effects on democracy. They argue that liberal democracies are the products of the hegemonic design of the United Kingdom and the United States. McDonald (2015) also asserts that the Democratic Peace Theory is the result of hegemony and the ability of the hegemon to shape the world order and system. According to McDonald (2015), Gartzke and Weisiger (2014) suggest that economic growth may lead to peace but the institutionalization of democracy will probably lead to wars due to the heterogeneity of the system. Powerful states try to diminish conflicts and wars in order to secure their access to international free trade.

\section{What Does the Democratic Peace Theory Assert?}

Democratic Peace, in short, expresses the fact that democratic states are less likely to use force and wage war against each other. The theory was introduced into International Relations literature in the 1980s. There have been numerous studies on Democratic Peace after the pioneering studies of Small \& Singer and Doyle (Russet, 1993). Even though the reasons underlying this type of peace are still being criticized, it is mostly accepted by scholars and experts that democratic states rarely wage war against each other.

The occurrence and development of the DPT literature in international relations are, in fact, a reaction to the Realist view on states and the international system. One of the most criticized arguments of Realism by the Liberals is that foreign policy is conducted independent from the domestic policy. In this sense, DPT is a theory trying to prove that domestic politics have an impact on foreign policy. By adopting this point of view, political regimes influence the states in making their decisions on war and peace (Moravcsik, 1997). While suggesting domestic policies affect foreign policy, two different approaches emerged in determining the level of analysis.

\section{Monadic Approach}

The Monadic Approach in DPT asserts that the foreign policy of a state is determined by the political regime, culture and characteristics of that state. The process of policymaking in terms of foreign affairs is shaped in this framework and neither international relations nor the system has any impact on policymaking. Accordingly, what determines foreign policy is the regime of the state itself. Foreign policy is produced domestically and pursued at international level (Quackenbush, 2009). Therefore, democratic states are peaceful by their nature regardless of with whom they enter into relations. This approach is rarely adopted by scholars since it suggests that democratic states are not only peaceful towards other democracies but also autocracies (de Mesquita et al., 1999, 2003; Chan, 1997; Dixon, 1994; Maoz and Russett, 1993; Oneal and Russett, 1997). 


\section{Dyadic Approach}

In the dyadic approach, the foreign policy of a state is determined not only by the regime type but also the interaction between states. According to the dyadic approach, states are in interaction and relation with other states and this interaction and relations with others shape their decisions and influence their decision-making process. The regime and the political vision of the state interact at international level while making their decisions. The regime of counterparts, regardless whether they are democratic or autocratic, is as important as domestic policies. If the other party is not a democracy, the democratic actors can be aggressive and warmongering (Rousseau et al., 1996). The foreign policy of a democratic state tends to be peaceful but its peace-loving attitude depends on the other party's system. Thus, the democratic state's foreign policy may change offensively. Furthermore, democratic states may be the first side to carry out a military attack (Rummel, R. J., 1985., Rousseau et al., 1996). In the light of the monadic and the dyadic approaches, democratic peace theorists hold two different explanations for DPT.

\section{Structural Explanation}

The structural explanation in the monadic approach suggests that citizens in democratic states are aware of their interests and are active participants in the decision-making process. Citizens take their actions by carrying out a cost-benefit analysis and make their decisions based upon the result to be expected. War does not only endanger the lives of citizens, but it also costs money and decreases their standard of life. Therefore, citizens, who are participants of the foreign policy-making process, are against war because of their rational evaluations. The ruling parties want to stay in power, so they do a cost-benefit analysis as well. War is expensive and undesirable. Hence, they need to be cautious in waging war in order to stay in power. Otherwise, the citizens will punish the governments and cast the rulers out of power. Therefore, rational governments will try to abstain from starting war (Tangerås, T. P., 2009., Reiter, D., \& Stam, A. C., 1998., Schultz, K. A., 1999). In democracies, legislation, execution and judiciary will check and balance each other, and thus, the check and balance system will make it difficult to wage war. The decision of entering into war cannot be made by a single individual or a specific group. The step taken in the direction of starting a war will require the participation of various institutions and different strata of the society. Thus, the check and balance system will restrict the decision of waging war, while any such restricted decision-making process will limit the reckless actions of the authority (Owen, 1994).

In the dyadic approach, both the governments and the citizens make cost-benefit analysis, as argued in the monadic approach. If a dispute occurs between two democracies, both sides will consider the costs and benefits of their actions and take steps accordingly. Consequently, they will opt for sustained peace. However, if one party is a democracy and the other one is an autocracy, the game will change. Since there are no institutions in the autocratic state 
to stall or stop waging a war, the security concerns of the democratic state will surge and they will prepare for war. If the autocratic party is assumed to be likely to wage war, the democratic state will strive for victory. Therefore, the democratic government will probably strike first. According to this explanation, international organizations and agreements play important roles in stopping aggression between states. Since the decision-making process in democratic states is translucent, the contentious behaviors will be deescalated by these supranational arrangements. Citizens are also able to participate in the process and correct the wrong decisions owing to the translucency of hostile decision-making attitudes (Russet, 1993).

\section{Normative explanation}

Normative explanation in the monadic approach acknowledges the peace among democracies to be a result of the norms, values and culture of the democratic state. This explanation suggests that citizens in democratic states want to implement peaceful resolutions to settle the disputes regardless of the other party's regime. They also want the oppression taking place in autocratic countries to end through peaceful solutions rather than calling for military action. According to the normative explanation, the structure and the institutions of the state are irrelevant. Liberal values are the fundamental components in decision-making (Elman, 1997).

Similar to the monadic approach, the dyadic approach emphasizes liberal values as well. When democracies get involved in conflict with other democratic states, they will act on norms based on their shared values in order to resolve the conflict. This same attitude would be adopted when they would deal with a non-democratic state unless the non-democratic party threatens or wages war in the first place. On the contrary, the democratic state will defend itself but it will never be the aggressor or the war-starter. Democratic countries will only exercise the right of self-defense. However, the culture and norms of the autocratic country will not be peaceful since these features will be based on cruelty and oppression (Russet, 1993).

Even though there have been two major explanations in DPT, scholars have begun to combine these two views. Accordingly, democratic states implement peaceful policies because of both their cultural characteristics and institutional components. Both these two factors are playing important roles in the decision-making process (Russet and Oneal, 2001)

\section{Hegemonic Peace Theory?}

This last section of the study will analyze the Democratic Peace Theory on grounds of the Coxian critical theory. Although Hobson (2011) examines DPT in terms of the philosophy of science by adopting the Coxian approach (1981) to the theoretical categorization, which 
distinguishes theories as problem-solving, and the critical theory, Cox (1983), moreover, incorporates Gramscian ideas to international relations. Gramsci (1971) explains hegemony as the dominance of the ruling class in the area of preference formation and the way of life of the society. He attaches great importance to this hegemonic relationship. In this regard, Hobson (2011) contends that DPT encourages liberal governments to reach a peaceful international order, and recognizes their right to use coercive and violent means against the existence of ethical liabilities. So, coercion is a means to maintain hegemony which is established on the basis of consent. Cox (1996) asserts that national hegemonic relations have an ambition to expand themselves towards the international system. In this sense, Devetak (2007) argues that democratic peace features expansionist characteristics concealed under the concept of humanitarian interventions to justify regime export. At this point, legitimacy of the ideology is one of the most important instruments in this process.

The structure of the system is composed of ideas, institutions and material capabilities. The emergence of a new mode of social relations in social production presents new hegemonic relations (Cox, 1987). Internationalization of the state can be achieved through institutions. Thus, social forces, form of state and world order, which are the components of historical structure, take new forms in the light of a new hegemonic design (Cox, 1981). According to Cox (1996), domination, moral and cultural leadership will constitute the basis for hegemonic permanence. At this point, while the Democratic Peace Theory encourages governments to initiate a democratic transition process, its theoretical framework presents democratic values, norms and governance as the universal way in achieving peace and reaching a higher level of wealth.

Another important concept in the Coxian critical theory is the historical block. The historical block emerges when society replaces the prevailing state structure (Cox 1983). As can be understood, the historical block is the new hegemonic force coming into power in a state. Therefore, international institutions offer a great opportunity for a new historical block to expand and assert its influence on the periphery. At this point, the United Nations Peace Keeping Operations serve to create new historical blocks in war-weary states.

The new global civil society comes together on the basis of newly defined common interests. The diffusion of the capitalist mode of production and the internationalization of democracy constitute a novel global system and produce new elites who are satisfied with the status quo. Therefore, this new level of satisfaction with the system reduces the likelihood of engaging in war-prone behaviors among the states. The relationship between the core and the periphery evolve into solidarity among imperialist powers. Hobson defines this relation as inter-imperialism. Likewise, Barkawi and Laffey (2001) conceptualize the lack of war as imperialist peace. This stance suggests that this approach of the Democratic Peace Theory strengthens the hegemonic position of the western liberal statehood and maintains liberal peace.

Hegemonic power uses the internationalization of production relations at the transnational scale to expand its hegemonic design over others. As a consequence of these newly 
emerging production relations, the social forces of historical structure are mobilized. This universalization of a new hegemonic class through international institutions empowers the formation of a new global civil society, which means the emergence of a transnational historical block. Although there are counter-hegemonic forces placed in other states, this new hegemonic class reflects the combination of the ideological and cultural leadership of the historical block and its domestic structure (Cox. 1981). As an instrument of democratic peace, international organizations are induced in non-democratic countries by employing structural adjustments and conditionality to convert them into democratic governments. Nevertheless, war is presented as a final solution to impose democracy.

For structural Marxism, this new kind of economic relations is a manifestation of neoliberal hegemony. The discourse of globalization, open trade and pro-market reforms serve to secure neo-liberalism and enable it to transfer its way of systemic dominance to the periphery (Wallerstein, 2004). International financial institutions, MNCs, mobility of capital, the hegemonic role of IMF and the World Bank support and facilitate the global expansion of capitalism and institutionalize the form of a liberal state. This is the result of the hegemonic position and the formation of a historical block organized around a new set of ideas and indicates the creation of a new world order. Periphery countries resort to international institutions with the idea of collaboration to change the system but they do not have the ability to change the system and find themselves working for the structure (Cox, 1996). From a different point of view, Patomäki (2016) establishes an interconnection between the liberal global economic order and democratic peace and suggests that these liberal economic tendencies do not eliminate the occurrence of potential violence and crusading ambitions within the system.

Marxist approaches regarding the Democratic Peace Theory expose that Democratic Peace is compatible with the "imperial peace" argument. Many studies in DPT literature, which show that democracies are very peaceful in their relations with each other, also show that democracies are generally less peaceful against non-democratic countries (Doyle, 1986). In other words; the peaceful effects of democracy arise only in relations with other democratic countries. This is consistent with the Democratic Peace Theory's normative explanations but contradicts its theoretical explanations. This is uncovered by Marxist approaches, which contend that democratic peace is a practice to preserve the positions of democratic countries at the center of the international system.

Moreover, the once colonial imperialist powers are seeking to preserve their dominant position in the international system by employing various concealed means. Exploitation of their former colonial ties in terms of politics, ideology, culture and military is in operation with the actions reinforcing capitalism (Sambo et al., 2017). While this hampers the tendency towards integrity among once-colonized countries, it also throws suspicion on the activities carried out by international organizations or the community. Additionally, the criticisms regarding the structure of the United Nations reveal the predominant role of the permanent members of the Security Council, their decisions within the organization, and their usage of the veto power in accordance with their national interests (Ade-Ibijola, 2015). 
In this regard, international actions mandated by the Security Council and/or backed by the Permanent Five to maintain international peace and security call for the neutrality and impartiality of operations (Rugeje and Maeresera, 2016).

\section{Military Intervention in Libya}

In this context, the military intervention in Libya led by the United States can be used as empirical evidence of how the DPT can be used to justify military intervention against enemy countries in the international arena. In 2010, a street vendor set himself on fire in front of a government office in Tunisia and his protest inspired street protests all over the Middle East and North Africa. These series of pro-democracy uprisings are referred to as the Arab Spring. The conflict sparked in the coastal town of Benghazi in February 2011 and spread all over Libya. The clashes occurred between the forces of Muammar Gaddafi and the armed opposition to his regime.

On 17 March 2011, the United Nations Security Council responded to the conflict in Libya by employing political, legal, humanitarian and military instruments (Metcalfe, 2011)as stated in Resolution 1973 (Kuperman,2015). Afterwards, the United States encouraged by Resolution 1973 initiated the Operation Odyssey Dawn (OOD) against Gaddafi's military forces. Within the framework of the OOD, the U.S. sought to conceptualize a new understanding of its overseas military actions by dividing the responsibility among its allies (Blomdahl, 2018). In this regard, NATO gained control of the US-led military intervention under the name of Operation Unified Protector on 27 March 2011 (Metcalfe, 2011). Although Russia and China initially supported the intervention in Libya, they casted suspicion on this military campaign owing to the fact that, although the Resolution was actually adopted to protect the civilian population in Libya from armed violence, NATO's intervention in Libya ended up with arming and helping rebels to overthrow the Gaddafi regime. Furthermore, differences of opinion between NATO and non-NATO members in the Security Council led to mistrust in the international community, believing that this intervention had been carried out under a hidden imperialist agenda. The term "all necessary measures" served as basis for the imperialist states to instrumentalize military interventions for the sake of satisfying their colonialist ambitions rather than protecting civilians and maintaining peace and stability (Falk, 2011).

The end goal of the imperialist states in the region was to establish liberal democratic regimes, where they would be able to carry out their imperialist ambitions in the post-colonial international system. The existence of the Gaddafi regime was not only a hindrance for the transition to democracy in Libya but also a threat against the success of the momentum gained by the Arab Spring (Kuperman, 2015).

Yet, Gaddafi had condemned the expansionist actions of the foreign colonialist in Africa and had adopted an anti-Western stance in the international arena. This stance of Gaddafi and his 
resistance against the rules of the imperialist structure facilitated to label Libya as one of the rogue states after $9 / 11$ (Cheikh, 2013). In this regard, the pretext of the imperialist powers to intervene in Libya was to replace the authoritarian Muammar Gaddafi regime with his pro-democratic opposition.

The intervention led by NATO in Libya was seemingly assessed as failure in total. Even though the aim of the operation was to democratize Libya, the country turned into a failed state where there was a considerable increase in killings and human rights abuses after the NATO-led military intervention. However, it can be interpreted that the secessionists in the eastern part of Libya took control of the region where the main oil and gas resources are located and they declared their own governmental structure in this area. This development served to weaken and divide Libya which paved the way for imperialist states to have easy access to the energy reserves. From the imperialist perspective, the intervention can be evaluated as a success.

According to the Marxist approach on the Democratic Peace Theory exposing that Democratic Peace is compatible with the "imperial peace" argument, the intervention in Libya carried out in 2011 unravels the imperialist desires of the Western countries disguised under the curtain of spreading democracy and protecting civilians against authoritative regimes.

\section{Conclusion}

Since the 1980s, the Democratic Peace Theory has been one of the most widely discussed topics in International Relations. Perpetual peace, initially conceived by Kant, laid the ground for universal peace among republics. However, Kant's approach has been modified by studies which replaced the notion of the republic with democracy. Empirical studies have shown that democracies are not pacifist as argued by Kant. In fact, these studies found out that democracies do not fight each other but they may adopt aggressive behaviors against non-democracies depending on the circumstances they face.

Various studies have been carried out in order to show the validity of this theory. A decade later, a great number of academicians started to criticize the theory from the realist point of view. These realist critics are valid to a large extent but they overlook the economic relations in explaining the behaviors of the states. At this point, this study recognizes the economic relations and the concept of hegemony by applying the critical theory to fully understand the dynamics of Democratic Peace.

The critical theory enables us to reveal the hidden functioning of problem-solving theories. Therefore, DPT appears to be a means of dominance for the ruling class. While the expansionist goals of the hegemon in the international system are exposed, humanitarian interventions and other practices of international organizations are utilized as the instrument of hegemonic permanence which aims to either export or build democratic counterparties in accordance with its hegemonic leadership in ideas, institutions and material capabilities. 
The case of the 2011 Libya military interventions is a manifestation of these expansionist tendencies of hegemonic powers. Thus, imperialist peace emerges on the basis of new state elites, who establish a governance understanding complying with the design of hegemony, while the diffusion of the capitalist mode of production and the internationalization of democracy are called forth through transnational relations.

\section{References}

Ade-Ibijola, A. O. (2015). The United Nations Security Council reforms and the permanent five challenge: A historical perspective. Journal of International Studies, 11, 131140.

Barkawi, T., \& Laffey, M. (2001). The imperial peace: Democracy, force and globalization. European Journal of International Relations, 5(4), 403-434.

Blomdahl, M. (2018). Interacting interests: Explaining President Obama's Libyan decision. European Journal of American Studies, 13(2), 2-13.

Chan, S. (1997). In search of democratic peace: Problems and promise. Mershon International Studies Review, 41(1), 59-91.

Cheikh, N. (2013). Stories behind the western-led humanitarian intervention in Libya: A critical analysis. African Journal of Political Science and International Relations, 7(3), 154-163.

Cox, R. (1983). Gramsci, hegemony and international relations: An essay in method. Millennium Journal of International Studies, 12(2), 162-175.

Cox, R. (1981). Social forces, states and world orders: Beyond international relations theory. Millennium Journal of International Studies, 10(2), 126-155.

Cox, R. (1996). Approaches to world order. Cambridge: Cambridge University Press.

Devetak, R. (2007). Between Kant and Pufendorf: Humanitarian intervention, statist anti-cosmopolitanism and critical international theory. Review of International Studies, 33(1), 151-174.

De Mesquita, B. B., Morrow, J. D., Siverson, R. M., \& Smith, A. (1999). An institutional explanation of the democratic peace. American Political Science Review, 93(4), 791807.

Dixon, W. J. (1994). Democracy and the peaceful settlement of international conflict. American Political Science Review, 88(1), 14-32.

Doyle, M. (1986). Liberalism and world politics. The American Political Science Review, 80(4), 1151-1168.

Doyle, M. (1983). Kant, liberal legacies, and foreign affairs. Philosophy and Public Affairs, 12(3), 205-235.

Elman, M. F. (1997). The need for a qualitative test of the democratic peace theory. Massachusetts: the MIT Press.

Falk, R. (2011, September 6). Chapter VII: a loophole for imperialists? Retrieved September 21, 2019, from https://www.aljazeera.com/indepth/opinion/2011/09/2011958322588 815.html 
Gartzke, E., \& Weisinger, A. (2013). Permanent friends? Dynamic difference and the democratic peace. International Studies Quarterly, 57(1), 171-185.

Hobson, C. (2011). Towards a critical theory of democratic peace. Review of International Studies, 37(4), 1903-1922.

Kant, I. (1957). Perpetual peace. New York: Liberal Art Press.

Kuperman, A. J. (2015). Obama's Libya debacle: How a well-meaning intervention ended in failure. Foreign Affairs, 94(2), 66-77.

Maoz, Z., \& Russet, B. (1993). Normative and structural causes of democratic peace. American Political Science Review, 87(33), 624-638.

Layne, C. (1994). Kant or cant: The myth of democratic peace theory. International Security, 19(2), 5-49.

McDonald, P. (2015). Great powers, hierarchy, and endogenous regimes: Rethinking the domestic causes of peace. International Organization, 69(3), 557-588.

Metcalfe, V. (2011, May). Friend or foe? Military intervention in Libya. Humanitarian

Policy Group. Retrieved from https:/www.odi.org/sites/odi. org.uk/files/odi-assets/ publications-opinion-files/7119.pdf

Moravcsik, A. (1997). Taking preference seriously: A liberal theory of international politics. International Organizations, 51(4), 518-520.

Oneal, J., \& Russet, B. (1997). The classical liberals were right: Democracy, Interdependence, and Conflict. International Studies Quarterly, 41(2), 267-292.

Owen, J. M. (1994). How liberalism produces democratic peace. International Security, $19(2), 87-125$.

Patomäki, H. O. (2016). Democracy in a globalised world. In Erskine, T., \& Booth, K. (Eds) International Relations Theory Today (pp. 190-201). Cambridge-Polity Press.

Pazienza, T. A. (2014). Challenging the democratic peace theory - The role of US-China relationship (Master's thesis), University of South Florida Commons, May.

Pugh, J. (2005). Democratic peace theory: A review and evaluation. Center for Mediation, Peace, and Resolution of Conflict Working Paper Series.

Quackenbush, S. L. (2009). Evaluating the monadic democratic Peace. Conflict Management and Peace Science, 26(3), 268-285.

Reiter, D., \& Stam, A. C. (1998). Democracy, war initiation, and victory. American Political Science Review, 92(2), 377-389.

Rousseau, D. L., Gelpi, C., Reiter, D., \& Huth, P. K. (1996). Assessing the dyadic nature of the democratic peace: 1918-88. American Political Science Review, 90(3), 512-533.

Rosato, S. (2003). The flawed logic of democratic peace theory. American Political Science Review, 97(4),585-602.

Rugeje, E. A., \& Maeresera, S. (2016). The United Nations Force Intervention Brigade: Wither the SADC/ICGLR synchronised peace support efforts in the Eastern Democratic Republic of Congo recurring conflict? Journal of International Studies, 12, 65-79.

Russet, B. (1993). Grasping the democratic peace: Principles for a Post-Cold war world. New Jersey: Princeton University Press.

Russet, B., \& Oneal, J. R. (2001). Triangulating peace: Democracy, interdependence, and international organizations. New York: W.W. Norton \& Company. 
Sambo, A. M., Othman, M. F., \& Omar, R. (2017). Liberia's post-1990 Ecomog Incursion: An assessment of anglophone-francophone dichotomy. Journal of International Studies, 13, 47-65.

Schumpeter, J. (2001). Capitalism, socialism, and democracy. New York: Harper Torchbooks.

Schumpeter, J. (1955). Imperialism and social classes. Cleveland: World Publishing.

Small, M., \& Singer, J. D. (1976). The war proneness of democratic regimes. Jerusalem Journal of International Relations, 1(1), 50-69.

Schultz, K. A. (1999). Do democratic institutions constrain or inform? Contrasting two institutional perspectives on democracy and war. International Organization, 53(2), 233-266.

Tangeras, T. P. (2009). Democracy, autocracy and the likelihood of international conflict. Economics of Governance, 10(2), 99-117.

Wallerstein, I. (2004). World system analysis: An introduction. London: Duke University Press. 